\title{
Impact of Maternal Occupation on Health and Nutritional Status of Preschoolers. (In Srinagar City)
}

\author{
Dr. Naheed Vaida. \\ Senior Associate Professor Institute of Home Science University of Kashmir Hazratbal, Srinagar, 190006
}

\begin{abstract}
The paper is an attempt to find out the impact of maternal occupation on health and nutritional status of preschool children. The nutritional status of children was assessed using anthropometric data, clinical assessment and diet record. The anthropometric data were taken and compared with ICMR growth charts and nutritional status was assessed by Hamwi Method, which is also used to find the degree of malnutrition (i.e. \% $I B W=($ actual weight / ideal body weight) $x$ 100). There is almost a negative deviation from the standards regarding almost all age groups of both working and non working mothers. It was found that $34 \%$ of preschoolers of working mothers usually skip meals, whereas only $12 \%$ preschoolers of non working mothers skipped meals. It was further found that children of employed mothers of $3+$ age group showed mild degree of malnutrition. It is evident that maternal occupation plays an indispensible task in seminal child feeding practices which may influence child's wellbeing and development.
\end{abstract}

\section{Introduction}

Women play multiple roles in the family that affect the health and well being of all family members. In almost all societies around the world, they are assigned by custom to be the primary caregivers to infants and children (UNDP 1995). Activities carried out by women such as breastfeeding, preparing food, collecting water and fuel, and seeking preventative and curative medical care are crucial for childs healthy development. In this modern era, most mothers have become part of the labour force compared to previous time. Maternal employment influences child feeding practices thus it reflects child's nutritional status (Farhana and Naleena 2012). In developing countries especially, such work is likely to be essential to family survival. Because of the time constraints women face, however, their roles as care-givers and as providers of family income may conflict with one another, with potentially important implications for the welfare of children. For developing countries, the implications for child nutrition, in particular, have been the subject of much empirical investigation and debate during the past two decades (Leslie 1989; Glick and Sahn 1998; Lamontagne et. al.; 1998). It has been noted that mothers who work may lack the time to adequately breastfeed or prepare nutritious meals for their young children, or to make use of public services designed to improve child nutrition ( Glick ; 2002).

Mothers exert strong influence over child feeding practices. This has been proven by a study done by Johannsen et al. (2006) which stated that child's weight was found to be closely related to mother's BMI but not fathers. Feeding practices play a vital role in determining child health and food preferences in later life. Better child nutritional status was also associated with better educational achievement among children in Malaysia (Shariff et al., 2000). A study done by Miller and Han (2008) claimed that, mothers with irregular working shifts will have disruption in meal preparation and activity routines. The study also reported that child's BMI increased significantly if their mothers worked at irregular schedule. Thus, children of employed mothers were more likely to have poor dietary habits and spent more time engaging in sedentary activity compared to children of unemployed mothers (Hawkins et al., 2009). A study conducted among Malaysian women aged between 25-35 years found that majority of working mothers had stopped breastfeeding in less than three months. In addition to this, Chinese and Indian mothers have higher risk of discontinuing breastfeeding compared to Malay mothers (Amin et al., 2011). This might be caused by inadequate breastfeeding facilities provided at workplace. This finding was also being supported in a study by Hawkins et al. (2007) which stated that the longer the length of mother's working hours, the less likely the mothers breastfed their children for at least 4 months. Working mothers were less likely to initiate and continue breastfeeding as they prefer infant formula (Grzywacz et al., 2010).

\section{Objectives}

To know and assess the nutritional status of preschool children.

To find out the dietary intake of preschoolers is as per RDA.

To determine the impact of maternal participation in the labor force on the nutritional status of preschoolers. 


\section{Material and Methods}

This is a comparative, observational and analytic study consisting of two pre- preparatory schools selected on simple random sampling technique. A total number of 100 preschoolers (50- whose mothers were working and 50- whose mothers were non working) in the age group of 2-6 years were selected.

Data was collected using a pre-tested self- designed questionnaire and after consent and proper instructions were given to the children accompanied by their mothers and every section of questionnaire was explained to them. Weight and height measurements were taken using proper scale and standard techniques. After building rapport, in depth interview of mothers was undertaken to record the social status of mothers covering following areas:

1. Mother's education.

2. Mother's employment.

3. Family structure.

The questionnaire was divided into different sections to obtain various types of information from the sample and these were.

I, General information: It includes the name, age, sex and maternal history of the sample and its variables( like age, qualification, occupation, monthly income, working hours etc.). It also elicited information about the nutritional awareness of mothers.

II, Anthropometric measurements: It includes the weight, height, mid arm circumference, head circumference, chest circumference and BMI of the sample.

III, Clinical assessment: In this, the sample was clinically assessed for visible symptoms of malnutrition. It includes the signs of malnutrition and deficiency diseases.

IV, Health status assessment: In this the mothers were interviewed about the general hygiene of their children, any recent illness, bizarre cravings, immunization status, taking of oral supplements, frequency of skipping meals and medical checkups conducted.

V, Nutritional Assessment (dietary history) - 24 hours food recall and food frequency questionnaire: It includes questions pertaining to the quantity and frequency of various foods consumed by the child in the course of one day. Mothers were asked to give a fair dietary recall of the food consumed by their children on the previous day in all the meals.

The data obtained was subjected to necessary statistical computation and nutritional status was assessed by Hamwi Method, this is also used to find the degree of malnutrition (i.e. \% IBW= (actual weight / ideal body weight) $\mathrm{x}$ 100) and was presented in the form of tables, pie charts and bar diagrams.

III. Results and Discussion

Table 1: Mean weight of samples.

\begin{tabular}{|l|l|l|l|l|l|l|l|}
\hline $\begin{array}{l}\text { AGE } \\
\text { (in years) }\end{array}$ & SEX & \multicolumn{3}{|l|}{ MEAN WEIGHT ( kgs) } & $\begin{array}{l}\text { STANDARD } \\
\text { WEIGHT* } \\
\text { (kgs) }\end{array}$ & S. E \\
\hline & & $\begin{array}{l}\text { No. of } \\
\text { sample }\end{array}$ & $\begin{array}{l}\text { Children } \\
\text { of } \\
\text { working } \\
\text { mothers }\end{array}$ & $\begin{array}{l}\text { No. of } \\
\text { sample }\end{array}$ & $\begin{array}{l}\text { Children } \\
\text { of non } \\
\text { working } \\
\text { mothers }\end{array}$ & & \\
\hline $2+$ & Male & 5 & 11.86 & 6 & 11.9 & 12.51 & 0.30 \\
\hline & Female & 3 & 11.1 & 2 & 11.5 & 11.67 & 0.30 \\
\hline $3+$ & male & 6 & 12.9 & 5 & 13.83 & 14.78 & 0.21 \\
\hline $4+$ & Female & 7 & 12.3 & 13 & 13.2 & 13.7 & 0.22 \\
\hline & Male & 5 & 15.84 & 7 & 16.0 & 16.12 & 0.18 \\
\hline $5+$ & Female & 15 & 14.55 & 6 & 15.3 & 15.85 & 0.22 \\
\hline & Male & 5 & 17.1 & 5 & 18.1 & 19.33 & 1.34 \\
\hline
\end{tabular}

Source: ICMR, 1990

S.E $=$ Standard Error

Average Weight $($ males $)=14.42 \mathrm{kgs} . \quad$ Average Weight $($ males $)=14.95 \mathrm{kgs}$.

Average Weight $($ females $)=13.69 \mathrm{kgs} . \quad$ Average Weight $($ females $)=14.62 \mathrm{kgs}$.

The mean weight of almost all the age groups (working as well as non- working) was less than the standard weight. As trend reveals, the pre- school years are very active years of a child, therefore the weight tends to 
fluctuate. The table reveals that there is a sudden decline in weight during the last years of pre- school years as shown. The cause of decline is not evident; however the factors may be the mothers work status as the average weight was $14.42 \mathrm{kgs}$ ( males) and $13.69 \mathrm{kgs}$ ( females)for children whose mothers were working whereas the average weight was $14.95 \mathrm{kgs}$ ( males and $14.26 \mathrm{kgs}$ ( females) whose mothers were house wives.

Table 2: Average consumption of calories / day by the sample (24 hours recall).

\begin{tabular}{|l|l|l|l|l|l|l|}
\hline Age (in years) & Sex & Mean Intake $(\mathrm{kcal} / \mathrm{d})$ & RDA(kcal/d) & \multicolumn{2}{|c|}{ Deviations (kcal) } \\
\hline & & $\begin{array}{l}\text { Children of } \\
\text { working } \\
\text { mothers. }\end{array}$ & $\begin{array}{l}\text { Children of } \\
\text { non working } \\
\text { mothers. }\end{array}$ & $\begin{array}{l}\text { Children of } \\
\text { working } \\
\text { mothers. }\end{array}$ & $\begin{array}{l}\text { Children of } \\
\text { non } \\
\text { working } \\
\text { mothers. }\end{array}$ \\
\hline $2+$ & Male & 1172.9 & 1184.1 & 1301 & -128.1 & -116.9 \\
\hline & Female & 1111.9 & 1147.9 & 1190 & -78.1 & -42.1 \\
\hline $3+$ & Male & 1354.7 & 1429.2 & 1463 & -103.8 & -33.8 \\
\hline $4+$ & Female & 1241.3 & 1275.5 & 1310 & -68.7 & -37.5 \\
\hline & male & 1447.2 & 1474.3 & 1778 & -330.8 & -303.7 \\
\hline $5+$ & female & 1347.1 & 1381.4 & 1643 & -295.9 & -261.6 \\
\hline & male & 1626.8 & 1712.8 & 1948 & -321.2 & -235.2 \\
\hline
\end{tabular}

Source: ICMR, 1990.

Working:

Average $=1400.4($ males $) \mathrm{kcal} / \mathrm{d}$

$=1295.6$ (females) $\mathrm{kcal} / \mathrm{d}$
Non working:

Average $=1450.1$ (males) $\mathrm{kcal} / \mathrm{d}$

$=1350.2$ (females) $\mathrm{kcal} / \mathrm{d}$

Table 2 depicts the mean caloric intake of the sample of both the groups almost children of all the age groups show a deviation from the RDA. It is evident from the above table that maximum deviation from RDA is seen in the age group of $4+$ years $(-330.8 \mathrm{kcal} / \mathrm{d}$, males) of the children of working mothers which is greater as compared to children of non working mothers, where the minimum deviation is also seen in the age group of $2+$ years $(-78.1 \mathrm{kcal} / \mathrm{d}$, males) of the children of employed mothers which is greater as compared to the children whose mothers are housewives( $-42.1 \mathrm{kcal} / \mathrm{d}$, males). The average intake of calories is $1400.4 \mathrm{kcal} / \mathrm{d}$ (males) and $1295.6 \mathrm{kcal} / \mathrm{d}$ (females) in children of working mothers and $1450.1 \mathrm{kcal} / \mathrm{d}$ (males) and $1350.2 \mathrm{kcal} / \mathrm{d}$ (females) in children whose mothers are housewives.

Fig 1: Number of meals skipped by the sample.

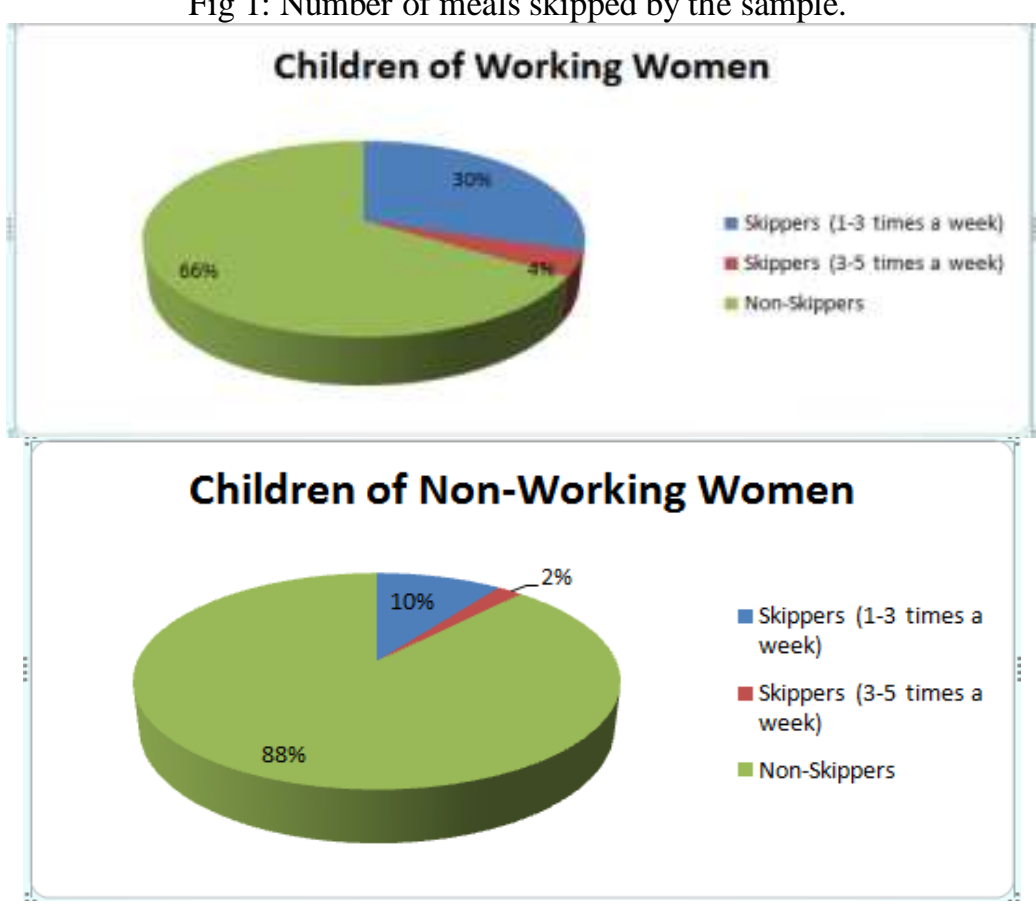

The above fig reveals that about $30 \%$ of preschoolers of working mothers usually skip meals $1-3$ times per week and 4\% skipped 3-5 times a week and rest were non skippers, whereas only $10 \%$ and $2 \%$ preschoolers of non working mothers skipped meals 1-3 times a week and 3-5 times per week respectively and rest were non skippers. 
Table 3: Degree of malnutrition in the sample:

\begin{tabular}{|c|c|c|c|c|c|c|c|c|}
\hline \multirow{2}{*}{$\begin{array}{l}\text { Age ( } \\
\text { in } \\
\text { years) } \\
\end{array}$} & \multirow[t]{2}{*}{ SEX } & \multicolumn{2}{|c|}{ 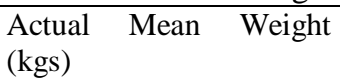 } & \multirow{2}{*}{$\begin{array}{l}\mathrm{IBW}^{*} \\
(\mathrm{kgs})\end{array}$} & \multicolumn{2}{|l|}{ IBW \% } & \multicolumn{2}{|c|}{ Degree of Malnutrition } \\
\hline & & $\begin{array}{l}\text { Children of } \\
\text { working } \\
\text { mothers }\end{array}$ & $\begin{array}{l}\text { Children of } \\
\text { non } \\
\text { working } \\
\text { mothers }\end{array}$ & & $\begin{array}{l}\text { Children of } \\
\text { working } \\
\text { mothers }\end{array}$ & $\begin{array}{l}\text { Children of } \\
\text { non } \\
\text { working } \\
\text { mothers }\end{array}$ & $\begin{array}{l}\text { Children of } \\
\text { working } \\
\text { mothers }\end{array}$ & $\begin{array}{l}\text { Children of } \\
\text { non } \\
\text { working } \\
\text { mothers }\end{array}$ \\
\hline \multirow[t]{2}{*}{$2+$} & Male & 11.86 & 11.9 & 12.51 & 4.8 & 95.1 & $\mathrm{~N}$ & $\mathrm{~N}$ \\
\hline & female & 11.1 & 11.5 & 11.67 & 95.1 & 98.5 & $\mathrm{~N}$ & $\mathrm{~N}$ \\
\hline \multirow[t]{2}{*}{$3+$} & Male & 12.91 & 13.83 & 14.78 & 87.3 & 93.5 & M.M & $\mathrm{N}$ \\
\hline & female & 12.3 & 13.2 & 13.7 & 89.7 & 96.3 & M.M & $\mathrm{N}$ \\
\hline \multirow[t]{2}{*}{$4+$} & Male & 15.84 & 16.0 & 16.12 & 98.2 & 99.2 & $\mathrm{~N}$ & $\mathrm{~N}$ \\
\hline & female & 14.55 & 15.3 & 15.85 & 91.7 & 96.5 & $\mathrm{~N}$ & $\mathrm{~N}$ \\
\hline \multirow[t]{2}{*}{$5+$} & Male & 17.1 & 18.1 & 19.33 & 88.4 & 93.6 & M.M & $\mathrm{N}$ \\
\hline & female & 16.84 & 17.07 & 18.67 & 90.1 & 91.4 & $\mathrm{~N}$ & $\mathrm{~N}$ \\
\hline
\end{tabular}

*Source: ICMR, 1990

N: Normal M.M: Mild malnutrition IBW: Ideal Body Weight.

The above table reveals that from the selected sample age group 2+, 4+ and 5+ ( females ) of employed mothers were in normal range of IBW \% based grade on nutritional status, whereas sample age group of $3+$ years showed mild degree of malnutrition in the grading of IBW\% based degrees of nutritional status. Although all age group of children of non working mothers were in the normal range of IBW\% based grade of nutritional status.

\section{Conclusion}

It is therefore concluded that there is almost a negative deviation from the standards regarding almost all age groups of both working and non working mothers. However difference was seen among the two groups. Almost all the calculated amount of nutrients was below RDA. This may be due to consumption of nutrient rich foods in limited amounts. According to gathered, information the time spent by mothers outside home was utilized by non working mothers to provide better nutrition and childcare to their children. To compensate this loss some children among working mothers were provided with oral supplements but that also did not help to alleviate the problem of deficiency diseases. In almost all cases the mean weight was less than the standard weight. Most of the under nutrition seen according to Hamwi method was due to the lack of care on the part of mothers who work outside.

\section{References:}

[1] Amin RM, Said ZM, Sutan R, Shah SA, Darus A \& Shamsuddin K (2011). Work related Determinants of Breastfeeding Discontinuation among Employed Mothers in Malaysia. Int. Breastfeed. J. Vol. 6, (In Press). 10.1186/1746-4358-6-4.

[2] Farhanah S and Naleena DM, (2012). The Association of Maternal Employment Status on Nutritional Status among Children in Selected Kindergartens in Selangor, Malaysia. Asian Journal of Clinical Nutrition, 4: 53-66.

[3] Grzywacz JG, Tucker J, Clinch CR \& Arcury TA (2010). Individual and job-related variation in infant feeding practices among working mothers. Am. J. Health Behav., 34: 186-196.

[4] Glick. P. ( 2002). Women's Employment and Its Relation to Children's Health and Schooling in Developing Countries: Conceptual Links, Empirical Evidence and Policies.pp 4-10.

[5] Glick, P., \& Sahn, D. (1998). Maternal labor supply and child nutrition in West Africa. Oxford

[6] Bulletin of Economics and Statistics. 60(3), 325-355.

[7] Hawkins SS, Griffiths LJ , Dezateux C \& Law C (2007). The impact of maternal employment on breast-feeding duration in the UK millenium cohort study. Public Health Nutr., 10: 891-896.

[8] Hawkins SS, Cole TJ \& Law C (2009). Examining the relationship between maternal behaviours in 5-years-old British children. J. Epidemiol. Commun. Health, 63: 999-1004.

[9] Johannsen, D.L., N.M. Johannsen and B.L. Specker, 2006. Influence of parent's eating behaviours and child feeding practices on children`s weight status. Obesity, 14: 431-439.

[10] Lamontagne JF, Engle PL \& Zeitlin, MF. (1998). Maternal employment, child care, and nutritional status of 12-18-month-old children in Managua, Nicaragua. Social Science \& Medicine. 46(3), 403-414.

[11] Leslie, J. (1989). Women's work and child nutrition in the third world. (pp. 19-58). In J. Leslie, and M. Paolisso, eds., Women, work, and child welfare in the third world. Boulder, CO: Westview Press.

[12] Leslie J \& Buvinic M. (1989). Introduction (pp. 1-17). In J. Leslie, and M. Paolisso, eds., Women, work, and child welfare in the third world. Boulder, CO: Westview Press.

[13] Miller DP \& Han WJ (2008). Maternal nonstandard work schedules and adolescent overweight. Am. J. Public Health, 98: 14951502.

[14] Shariff ZM, Bond JT \& Johnson NE (2000). Nutrition and educational achievement of urban primary schoolchildren in Malaysia. Asia-Pac. J. Clin. Nutr., 9: 264-273.

[15] United Nations. (1995). World's women 1995: Trends and statistics. New York: United Nations.

[16] United Nations Development Programme. (1995). Human Development Report. New York: Oxford University Press. 